\title{
Sugarcane expansion in the Capivara River hydrographic basin (SP) between 1977 and 2010
}

\author{
Expansão da cana-de-açúcar na bacia hidrográfica do Rio da \\ Capivara (SP) entre 1977 e 2010
}

\author{
Walquíria Silva Machado; Tiago Santos Telles²; João Tavares Filho $^{3 *}$
}

\begin{abstract}
Remote sensing and geographic information systems (GIS) with applied digital image-processing (DIP) techniques are essential tools for maintaining land-use records over time. The sugar-ethanol industry has increased over the last 30 years in areas of the Paranapanema Valley in the Western São Paulo Plateau, which is considered one of the last major regions of São Paulo State, Brazil with soil, climate, and relief favorable for expanding sugarcane production. However, there is still no detailed study on changes in land-use and land occupation in the Capivara River basin. In this context, this study aimed to evaluate the expanding land-use toward sugarcane crop production throughout the middle course of the Capivara River basin, southwestern São Paulo, Brazil between 1970 and 2010 using remote sensing. Thus, thematic maps referring to soil types and the land-use of the area were organized using GIS tools, and the cartographic data were used to prepare maps with ArcMap 9.3 software. The results showed that there was a $31.24 \%$ expansion in sugarcane crops within the Capivara River basin area, from $4.32 \%$ in 1977 to $35.56 \%$ in 2010 . This expansion mainly occurred in areas previously used for pastures but may have also occurred in areas of forest remnants.
\end{abstract}

Key words: Remote sensing, geographic information systems, land-use

\section{Resumo}

O sensoriamento remoto e o geoprocessamento com aplicação das técnicas de processamento digital de imagens são ferramentas fundamentais para a manutenção dos registros do uso do solo ao longo do tempo. Áreas do Vale do Paranapanema, no Planalto Ocidental Paulista, vêm nos últimos 30 anos aumentando seu polo sucroalcooleiro, por ser considerada uma das últimas grandes regiões do estado de São Paulo com solo, clima e relevo favorável para a expansão desta cultura. Entretanto, ainda não se tem um estudo pormenorizado sobre as mudanças no uso e na ocupação do solo na bacia do Rio da Capivara. Nesse contexto, esse estudo teve por objetivo avaliar, com o uso de sensoriamento remoto, a expansão do uso do solo com a cultura da cana-de-açúcar no curso médio da bacia do Rio da Capivara, sudoeste paulista, entre as décadas de 1970 e 2010. Para tanto, foram organizados mapas temáticos referentes aos tipos de solos e uso da terra da área, tendo sido usadas as ferramentas englobadas pelo SIG, sendo as cartas elaboradas com a utilização do software ArcMap 9.3. Os resultados mostraram que a cultura da cana-de-açúcar teve uma expansão de $31,24 \%$ na área da bacia do Rio da Capivara, passando de 4,32\% em 1977 para 35,56\% em 2010. Essa expansão ocorreu principalmente sobre áreas antes utilizadas com pastagens, mas também pode ter ocorrido sobre áreas de remanescentes florestais.

Palavras-chave: Sensoriamento remoto, sistemas de informação geográfica, uso do solo

${ }^{1}$ Geógrafa, Dra em Agronomia pela Universidade Estadual de Londrina, UEL, Londrina, PR, Brasil. E-mail: w.mach@hotmail.com

2 Dr., Pesquisador do Instituto Agronômico do Paraná, IAPAR, Londrina, PR, Brasil. E-mail: telles@iapar.br

${ }^{3}$ Prof. Dr. Associado, Dept ${ }^{\circ}$ de Agronomia, Centro de Ciências Agrárias, UEL, Londrina, PR, Brasil. E-mail: tavares@uel.br

* Author for correspondence 
Global interest in reducing dependence on fossil fuels and diversifying the energy matrix to mitigate global warming has aroused attention for biofuels, especially ethanol from sugarcane produced in Brazil (GOLDEMBERG, 2007; NASS et al., 2007). Thus, the growing demand for sugarcane-derived products has caused an intense search for areas suitable for its cultivation.

Sugarcane (Saccharum spp.) is a monocot, allogamous, semi-perennial plant adapted to tropical and subtropical climates that has occupied large tracts of land in Brazil, which is the largest producer and exporter of this commodity worldwide. Its production is concentrated in the south-central and northeastern states, especially in São Paulo state, which is responsible for approximately $60 \%$ of Brazilian sugar and ethanol production (RUDORFF et al., 2010). Especially since 2000, this context has led to the conversion of areas of pastures and native forest into sugarcane crops, and livestock activity has relinquished $48.31 \%$ of its area for sugarcane crop production (DURIGAN et al., 2007; NOVO et al., 2010). Additionally, mainly after 2003, with the advent of flex-fuel cars in Brazil, there was even greater demand for sugarcane production to obtain ethanol, which accentuated expansion of this crop (ADAMI et al., 2012).

Remote sensing and geographic information systems (GIS) with applied digital imageprocessing (DIP) techniques comprise tools that allow for viewing changes in agricultural landuse and maintaining land-use records over time (BLASCHKE, 2010; KENNEDY et al., 2009).

Sugarcane is considered a semi-perennial crop and is planted in large areas, which are favorable characteristics for identification via satellite imagery and consequent analysis and mapping of its land cover on the Earth's surface. This mapping of areas with sugarcane crop using remote sensing has been performed via visual interpretation of Landsat multitemporal images, providing precise and consistent results (REIS et al., 2005; VIEIRA et al., 2012).
The sugar-ethanol industry has increased over the last 30 years in areas of the Paranapanema Valley, in the Western São Paulo Plateau, which is considered one of the last major regions of São Paulo State with soil, climate, and relief favorable for expanding sugarcane production.

Thus, the aim of this study was to evaluate expanding land-use for the sugarcane crop in the middle course of the Capivara River basin in southwestern São Paulo from 1970 to 2010 via remote sensing data.

The study area of the Capivara River basin $\left(3,432.23 \mathrm{~km}^{2}\right)$ is within the Paranapanema Valley region in the western São Paulo Plateau. It comprises the southwestern region of São Paulo State, located in the Middle Paranapanema (22 ${ }^{\circ} 29^{\prime} \mathrm{S}$ and $50^{\circ} 37^{\prime}$ W) (Figure 1).

The Capivara River basin area is characterized by hilly relief, supported by basic sedimentary and igneous rocks of the Paraná basin and predominantly covered by Oxisols, Nitosols, and Ultisols. These soils, which occupy an area equivalent to $33,881.90$ ha, are the result of pedogenetic processes that occurred in the sandstone rocks of the Bauru Group (Caiuá, Santo Anastácio, Adamantina and Marília formations) and the basaltic rocks of the São Bento Group (Serra Geral formation) (LEPSCH et al., 1977a).

The Western São Paulo Plateau covers an area of approximately $50 \%$ of São Paulo State, ranging from the sandstone basaltic cuestas province to the northern (Rio Grande), western (Paraná River), and southern boundaries (Paranapanema River). The following types of relief are generally found throughout southwestern São Paulo State: large hills, medium hills, elongated hills and spurs, sedimentary tables, floodplains, and river terraces described as gentle, wavy relief with mean slopes ranging from 3 to $8 \%$ (LEPSCH et al., 1977b). Savannah (Brazilian "Cerrado" or "Cerradão" biomes) is the primary vegetation of the area. 
The climate is mesothermal subtropical (Cwa), according to the Köppen classification, and is characterized by hot and rainy summers with mean temperatures higher than $22^{\circ} \mathrm{C}$ and by winters with mean temperatures lower than $18^{\circ} \mathrm{C}$ as well as by well-defined seasons and a mean annual rainfall of $1,359 \mathrm{~mm}$.

Figure 1. Location of the Capivara River basin (SP).

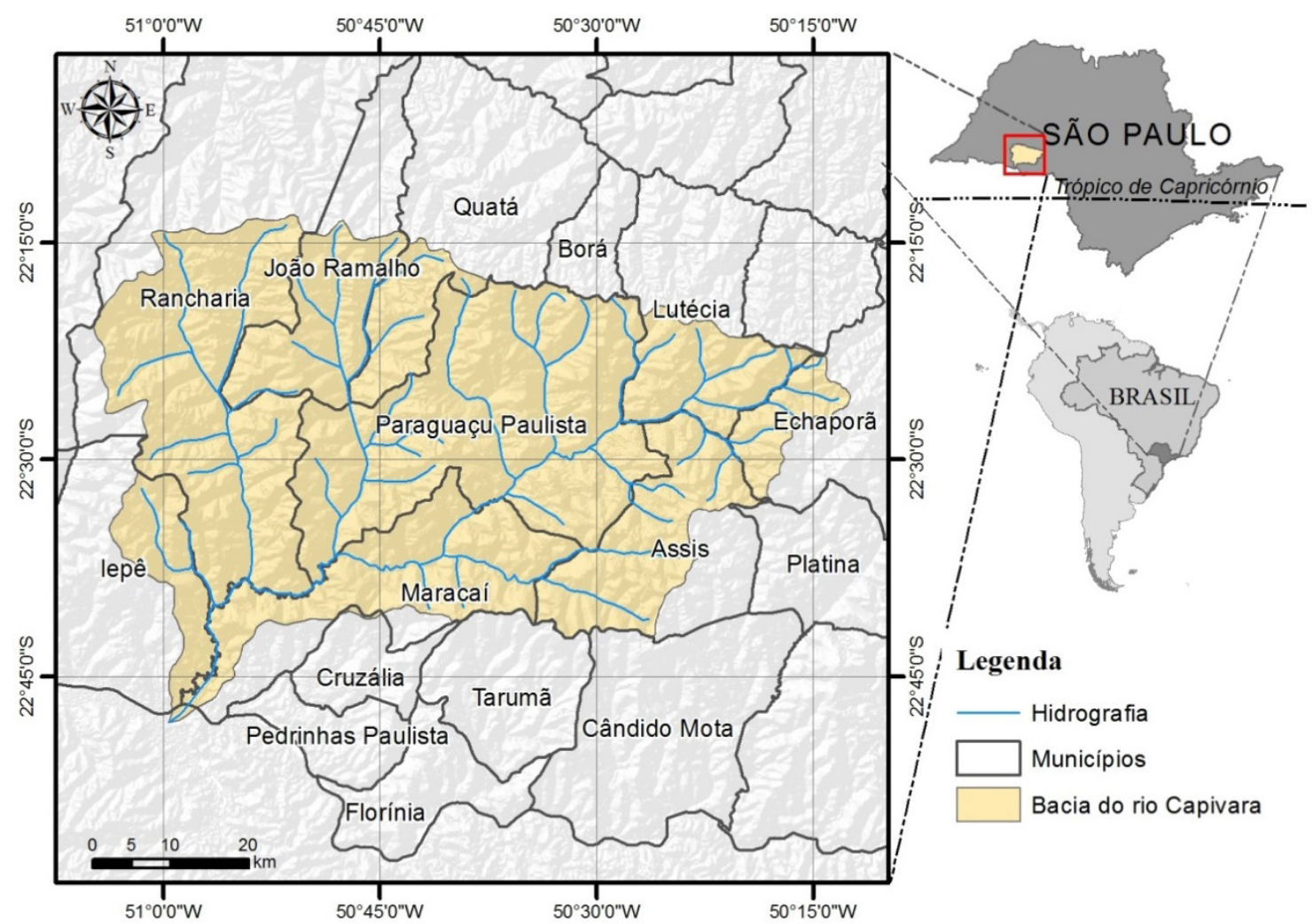

Using GIS tools, the mapping necessary for studying the evolving land-use in the Capivara River basin was performed using the ArcMap 9.3 software.

The Universal Transverse Mercator Projection System was used, with a point of origin at the intersection between the Equator and the meridian at $57^{\circ} \mathrm{W}$ GR, plus the constants $10,000 \mathrm{~km}$ and 500 $\mathrm{km}$, respectively. The Horizontal Datum used was SAD 69 zone 21S, and the Vertical Datum used was Imbituba, SC.

All the bases were manipulated with GIS tools so that the information would remain standardized within the system of projections defined and according to the display scale selected for the study $(1: 300,000)$.

For the multi-temporal analysis of the study area, satellite images (LANDSAT 2 MSS with $80 \mathrm{~m}$ of spatial resolution and an overpass date of 4/24/1977 and LANDSAT 5 TM with $30 \mathrm{~m}$ of resolution and an overpass date of 6/16/2010) were used. The data were selected by intervals of approximately 30 years because they represent specific historical moments that are distinct enough regarding land-use; the 1977 image represents the transition period between the season's crops and the commodity crops, and the 2010 image represents 
the current stage of land occupation. Additionally, the images with the best quality were selected, i.e., those with fewer clouds and residues. The images were obtained by the Brazilian National Institute of Spatial Studies (Instituto Nacional de Pesquisas Espaciais - INPE), the Brazilian National Water Agency (Agência Nacional das Águas - ANA), and the Brazilian Institute of Geography and Statistics (Instituto Brasileiro de Geografia e Estatística IBGE). The images were treated using the SPRING 5.0 software of the INPE.

The image treatment process was carried out as follows: initially, the raw image went through the image recording process (georeferencing); twelve control points were selected in the georeferenced cartographic base, and the corresponding points in the images received the recorded UTM coordinates of each point. After being georeferenced, the images underwent a contrast process to better visualize the targets of the images. Because the LANDSAT images were multi-spectral, they allowed for the creation of colorful images by applying one color to each band and using the 3R 4G 5B composition. These images were segmented and classified using the MaxVer classifier (maximum likelihood) with $99.9 \%$ linear acceptance, and thus, the land-use types and vegetation types could be identified.

The land-use and occupation maps, together with the divisions of the land-use classes in the Capivara River basin from 1977 to 2010, are shown in Figure 2A and 2B and Table 1. In 1977, the area was predominantly used as pasture $\left(2,056.66 \mathrm{~km}^{2}\right.$, $59.91 \%$ of the total), followed by agricultural production of grains $\left(355.28 \mathrm{~km}^{2}, 10.35 \%\right.$ of the total) and sugarcane (only $148.24 \mathrm{~km}^{2}, 4.32$ $\%$ of the total). In 1977, no degraded areas were detected. In 2010, the plurality of the basin area was used for sugarcane production $(1,220.57$ $\mathrm{km}^{2}, 35.56 \%$ of the total), followed by pasture $\left(975.57 \mathrm{~km}^{2}, 28.42 \%\right.$ of the total) and agricultural production of grains $\left(757.57 \mathrm{~km}^{2}, 22.07 \%\right.$ of the total). In contrast to 1977 , in $2010,82.72 \mathrm{~km}^{2}(2.42$
$\%)$ of degraded agricultural areas were detected. The sugarcane crop expanded $31.24 \%$ within the Capivara River basin area, from $4.32 \%$ in 1977 to $35.56 \%$ in 2010.

Thus, it is important to note that there was an increase of $31.24 \%$ in the area for sugarcane production, $11.72 \%$ for agricultural production of grains and $2.42 \%$ for degraded areas between 1977 and 2010 in the Capivara River basin. In contrast, there was a $13.89 \%$ decrease in the forested area and a $31.49 \%$ decrease in the pasture area. The results show that the areas of forest and pasture gave the most way for space for sugarcane crop expansion and agricultural grain production in the Capivara River basin. Additionally, this expanding sugarcane production did not compromise areas for agricultural grain production (SATOLO; BACCHI, 2009). Thus, the increase in areas for sugarcane production occurred mainly to the detriment of degraded pasture areas but may have also occurred within areas of forest remnants. However, according to Sparovek et al. (2009), intensification and occupation of new areas for sugarcane crop in Brazil did not generally directly contribute to deforestation.

According to Adami et al. (2012), expanding sugarcane production throughout São Paulo State between 2000 and 2007 mostly occurred in pasture areas (64.72\%). According to Rudorff et al. (2010), sugarcane has expanded in São Paulo State in recent decades, not only in traditional regions, such as Ribeirão Preto, Franca, and Barretos, but also in regions historically focused on livestock production, such as in western and southwestern São Paulo State. According to Camargo et al. (2008), between 2001 and 2006, there was a rapid growth in sugarcane-cultivated areas throughout the entire São Paulo territory. During this period, the area cultivated for this crop increased by approximately $37.43 \%$, especially within the Assis region, southwestern São Paulo, where the expansion was approximately $76 \%$. 
Figure 2. Changes in land-use and land occupation in the Capivara River basin (SP) between 1977 and 2010.

A.

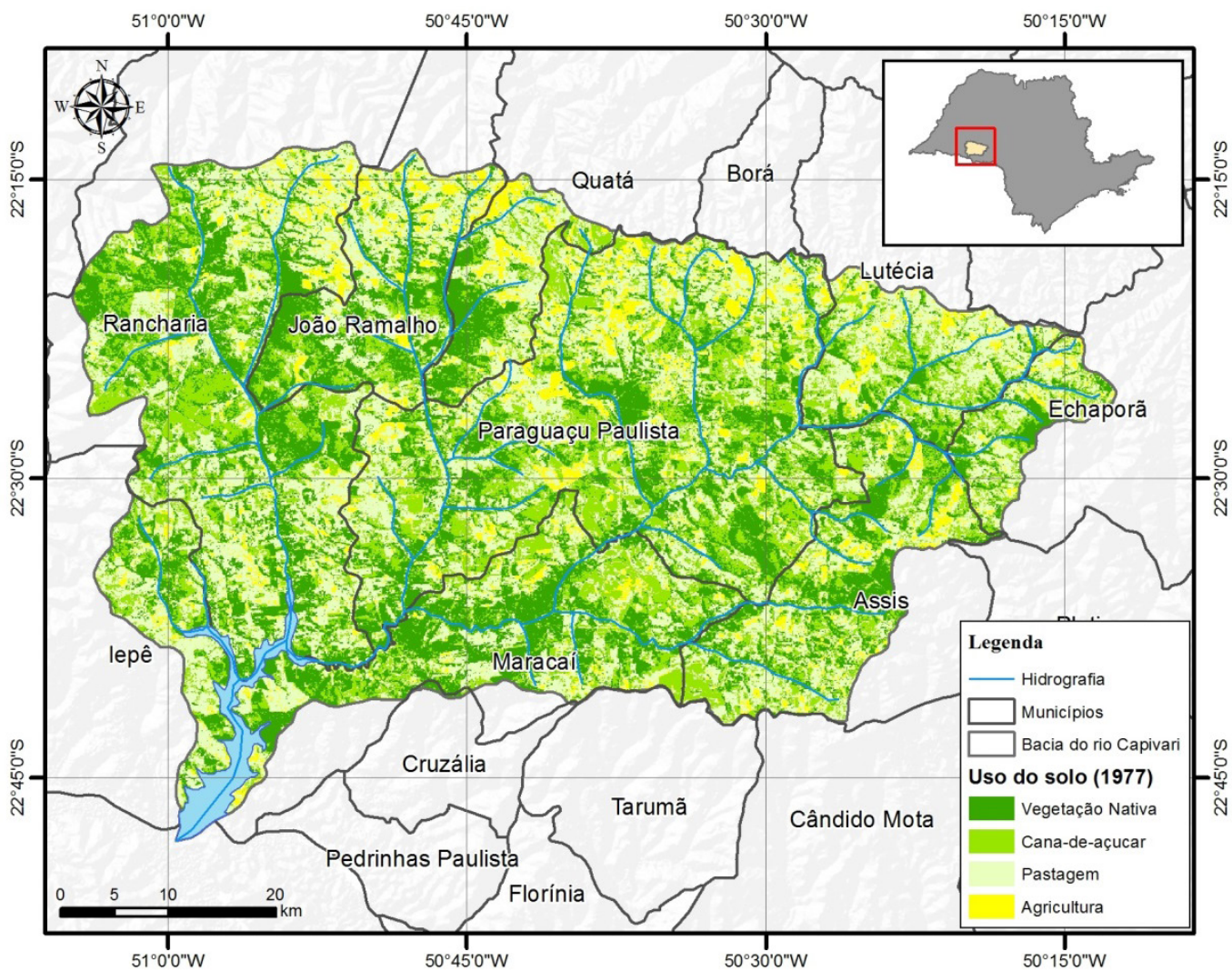

B.

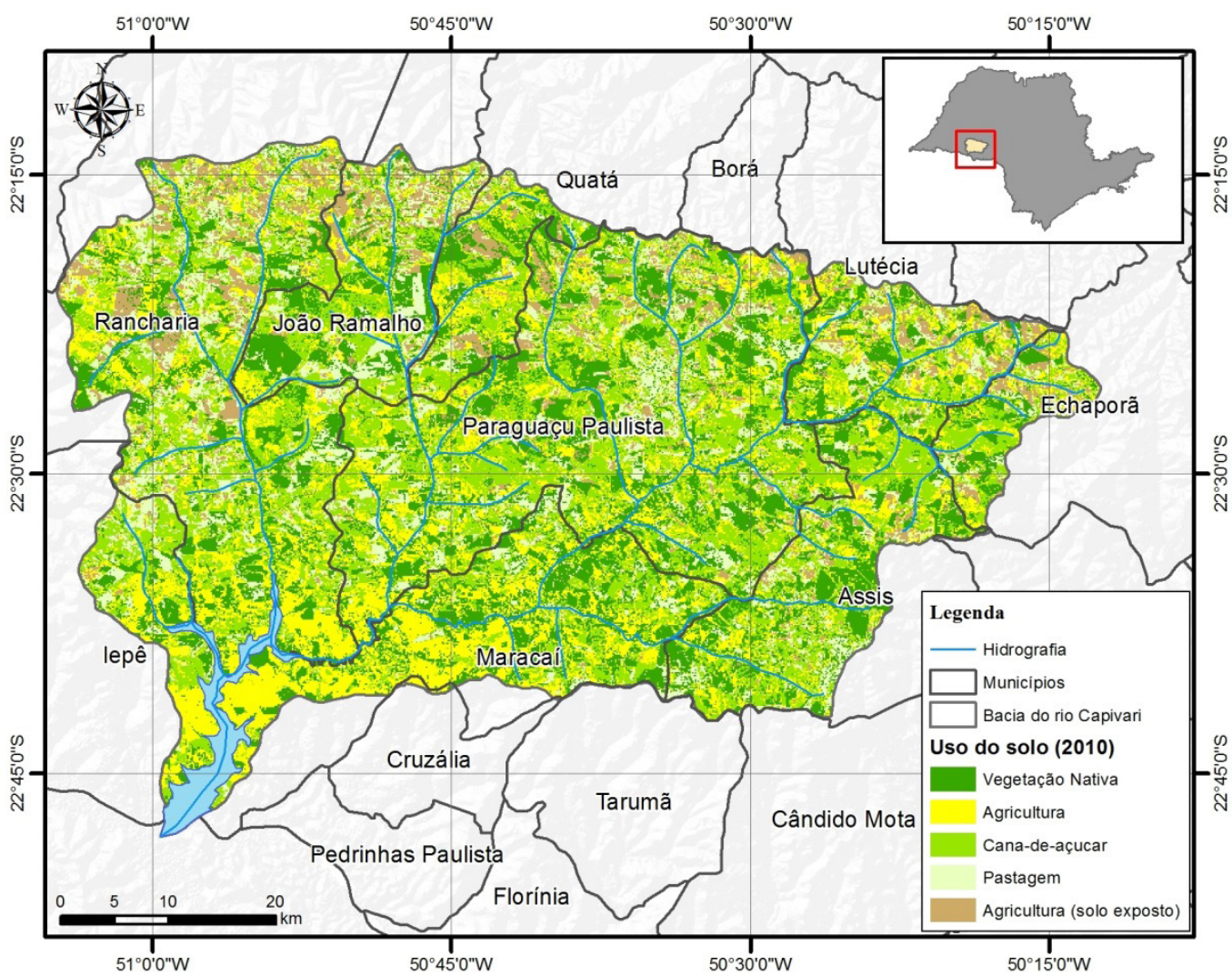


Table 1. Land-use in the Capivara River basin between 1977 and 2010.

\begin{tabular}{|c|c|c|c|c|c|}
\hline \multirow[t]{2}{*}{ Class } & \multirow[t]{2}{*}{ Color in the maps } & \multicolumn{2}{|c|}{ Area in 1977} & \multicolumn{2}{|c|}{ Area in 2010} \\
\hline & & $\mathrm{km}^{2}$ & $\%$ & $\mathrm{~km}^{2}$ & $\%$ \\
\hline Lake & Blue & 44.04 & 1.28 & 44.04 & 1.28 \\
\hline Forest remnant & Dark green & 828.53 & 24.14 & 351.76 & 10.25 \\
\hline Pasture & Sand & $2,056.66$ & 59.91 & 975.57 & 28.42 \\
\hline Agriculture (grains) & Yellow & 355.28 & 10.35 & 757.57 & 22.07 \\
\hline Degraded areas (exposed soil) & Brown & - & - & 82.72 & 2.42 \\
\hline Sugarcane & Light green & 148.24 & 4.32 & $1,220.57$ & 35.56 \\
\hline Total & & $3,432.23$ & 100.00 & $3,432.23$ & 100.00 \\
\hline
\end{tabular}

There are extensive pasture areas within the southwestern region of São Paulo State that are sufficient not only for the sugarcane sector but also for other agricultural activities to expand. However, it is important to test how expanding sugarcane production will interact with livestock production (moving, competing, coexisting, integrating) because sugarcane crops and pastures are usually not located in the same region. Within the study area, for example, with livestock in constant decline, the land used for pastures, especially degraded ones, was incorporated into sugarcane planting. For Lima Filho et al. (2014), these dynamics are a result of the return that the pasture owners can earn in leasing their land for sugarcane production. Thus, the ranchers were displaced to other areas or even "transformed" into sugarcane growers (SPAROVEK et al., 2009).

Additionally, the forest remnant area in the Capivara River basin, based on 2010 data, is half of what it should be, considering the Brazilian forest code published by the Brazilian President's office on May 28, 2012, Law 12,651. According to this code, the microbasin in question does not meet the minimum required by law because, considering the total area of the basin $\left(3,432.26 \mathrm{~km}^{2}\right), 20 \%$ of the predominant biome should be meant for the legal reserve (ARL), i.e., $686.45 \mathrm{~km}^{2}$, and a forested riparian area (permanent preservation area - PPA) that varies from 5 to $8 \mathrm{~m}$ for most of the properties of the microbasin studied, counted from the edge of the channel to the natural margin of the rivers.
Adami et al. (2012), in performing an analysis of changing land-use within South-Central Brazil during the first decade of the 21 st century, highlighted that intense expansion of the sugarcane crop was mainly triggered by economic factors related to the increased commodity demands for ethanol and sugar production. In the Capivara River hydrographic basin, rapidly replacing areas of forest and pasture with sugarcane results mainly from environmental factors (climate and soil) that favor the establishment and high production of semiperennial crops and financial factors represented by the low profitability of extensive livestock activity compared with sugarcane production, as reported by Adami et al. (2012), Camargo et al. (2008), and Durigan et al. (2007).

In summary, the analyses performed based on the map of evolving land-use and land cover and the quantifications of the changes over the last 33 years allowed for a more detailed understanding of the transformations that occurred in the Capivara River hydrographic basin. Although the expansion and intensification of land-use for sugarcane production occurred mainly on anthropic areas that were previously degraded, especially pasture areas, it could also have occurred on areas of forest remnants.

Finally, the information obtained using remote sensing techniques combined with DIP and GIS allowed for the efficient construction of the maps of land-use and land cover in the Capivara River 
hydrographic basin (SP) from 1977 to 2010 to test the changes in land-use and land occupation.

\section{Acknowledgments}

We thank the Brazilian National Council for Scientific and Technological Development (Conselho Nacional de Desenvolvimento Cientifico e Tecnológico - CNPq) and the Brazilian Federal Agency for the Support and Evaluation of Graduate Education (Coordenação de Aperfeiçoamento de Pessoal de Nível Superior - CAPES) for providing grants.

\section{References}

ADAMI, M.; RUDORFF, B. F. T.; FREITAS, R. M.; AGUIAR, D. A.; MELLO, M. P. Remote sensing time series to evaluate direct land use change of recent expanded sugarcane crop in Brazil. Sustainability, Basel, v. 2, n. 4, p. 574-585, 2012.

BLASCHKE, T. Object based image analysis for remote sensing. ISPRS Journal of Photogrammetry and Remote Sensing, Amsterdam, v. 65, n. 1, p. 2-16, 2010.

CAMARGO, A. M. M. P.; CASER, D. V.; CAMARGO, F. P.; OLIVETTE, M. P. A.; SACHS, R. C. C.; TORQUATO, S. A. Dinâmica e tendência da expansão da cana-deaçúcar sobre as demais atividades agropecuárias, estado de São Paulo, 2001-2006. Informações Econômicas, São Paulo, v. 38, n. 3, p. 47-66, 2008.

DURIGAN, G.; SIQUEIRA, M. F.; FRANCO, G. A. D. C. Threats to the Cerrado remnants of the state of São Paulo, Brazil. Scientia Agricola, Piracicaba, v. 64, n. 4, p. 355-363, 2007.

GOLDEMBERG, J. Ethanol for a sustainable energy future. Science, Washington, v. 315, n. 5813, p. 808-810, 2007.

KENNEDY, R. E.; TOWNSEND, P. A.; GROSS, J. E.; COHEN, W. B.; BOLSTAD, P.; WANG Y. Q.; ADAMS, P. Remote sensing change detection tools for natural resource managers: understanding concepts and tradeoffs in the design of landscape monitoring projects. Remote Sensing of Environment, New York, v. 113, n. 7, p. 13821396, 2009.
LEPSCH, I. F.; BUOL, S. W.; DANIELS, R. B. Soil landscape relationships in the Occidental Plateau of São Paulo, Brazil: I. Geomorphic surfaces and soil mapping units. Soil Science Society of America Journal, Madison, v. 41, n. 1, p. 104-109, 1977a.

Soil-landscape relationships in the Occidental Plateau of São Paulo State, Brazil: II. soil morphology, genesis, and classification. Soil Science Society of America Journal, Madison, v. 41, n. 1, p. 109-115, 1977 b.

LIMA FILHO, R. R.; AGUIAR, G. A. M.; TORRES JUNIOR, A. M. Cana-de-açúcar: arrendar ou produzir? Agroanalysis, Rio de Janeiro, v. 34, n. 5, p. 26-27, 2014.

NASS, L. L.; PEREIRA P. A. A.; ELLIS, D. Biofuels in Brazil: an overview. Crop Science, Madison, v. 47, n. 6, p. 2228-2237, 2007.

NOVO, A., JANSEN, K.; SLINGERLAND, M.; GILLER, K. Biofuel, dairy production and beef in Brazil: competing claims on land use in São Paulo State. Journal of Peasant Studies, London, v. 37, n. 4, p. 769-792, 2010.

REIS, T. E. S.; BARROS, O. N. F.; REIS, L. C. Determinação do uso do solo do município de Bandeirantes, Estado do Paraná, através de imagem do Landsat $7 \mathrm{Etm}+$ e técnicas de geoprocessamento. Semina: Ciências Agrárias, Londrina, v. 26, n. 1, p. 41-48, 2005.

RUDORFF, B. F. T.; AGUIAR, D. A.; SILVA, W. F.; SUGAWARA; L. M.; ADAMI, M.; MOREIRA, M. A. Studies on the rapid expansion of sugarcane for ethanol production in São Paulo State (Brazil) using Landsat Data. Remote Sensing, Basel, v. 2, n. 4, p. 1057-1076, 2010.

SATOLO, L. F.; BACCHI, M. R. P. Dinâmica econômica das flutuações na produção de cana-de-açúcar. Economia Aplicada, Ribeirão Preto, v. 13, n. 3, p. 377-397, 2009.

SPAROVEK, G.; BARRETTO, A.; BERNDES, G.; MARTINS S.; MAULE, R. Environmental, land-use and economic implications of Brazilian sugarcane expansion 1996-2006. Mitigation and Adaptation Strategies for Global Change, Heidelberglocal, v. 14, n. 3, p. 285-298, 2009.

VIEIRA, M. A.; FORMAGGIO, A. R.; RENNÓ, C. D.; ATZBERGER, C.; AGUIAR, D. A.; MELLO, M. P. Object-based image analysis and data mining applied to a remotely sensed Landsat time-series to map sugarcane over large areas. Remote Sensing of Environment, New York, v. 123, p. 553-562, 2012. 
